\title{
Practical Application of Quality Tools in the Cast Iron Foundry
}

\section{Robert Ulewicz}

Institute of Production Engineering, Faculty of Management, Czestochowa University of Technology. Armii Krajowej 19B, 42-201 Czestochowa, Poland. E-mail: ulewicz@zim.pcz.pl

New requirements placed to products, and hence to materials from which they are produced resulted in widespread use of instruments of quality assurance. Depending on destination of the product, its manufacturing process is burdened with the need to implement quality assurance systems, recording and analysing data, and also a process of continuous improvement. The article presents the results of practical use of selected quality tools in iron foundry. In order to determine the level of incompatibility of manufactured products the analysis was carried out based on the use of Ishikawa diagram and Pareto-Lorenz method. The results of the above analysis were defined as a starting point to develop a dendrogram and to determine the variant solution to the problem using programming of decision-making process, there was also developed diagram of the manufacturing process of iron castings.

Keywords: Quality Tools, Cast Iron Foundry

\section{References}

[1] ULEWICZ, R. (2003). Quality control system in production of the castings from spheroid cast iron, In: Metalurgija, Volume 42, Issue 1, pp. 61-63.

[2] DIMA, I. C., GRZYBOWSKI, A. (2013). Statistical modeling of the mechanical properties of the heavy steel plates - dealing with the ill conditioned data, In: Metalurgia International, Volume 18, Issue 1, pp. 11-14.

[3] ŚLUSARCZYK, B., DIMA, I. C., KOT, S. (2013). Consolidation trends in wold steel industry, In: Metalurgia International, 2013, Volume 18, Issue 7, pp. 178-182.

[4] JURAN, J. M. (1988). Quality Control Handbook, McGraw-Hill, New York.

[5] DEMING, W. E. (1982). Quality, Productivity and Competition Position, MIT Press, Cambridge: Massachusetts.

[6] AKAO, Y. (1995). Quality Function Deployment. Integration Customer Requirements into Product Design. Productivity Press, Portland.

[7] WEISS, E., PAWĘSKA M. (2013). Enterprise-new challenges theory and practice, Mobile, Alabama State, USA, New York University.

[8] BORKOWSKI, S.,ULEWICZ, R. (2008). Zarządzanie produkcja. Systemy Produkcyjne, Oficyna Wydawnicza Humanitas, pp. 237, Sosnowiec.

[9] KRYNKE, M., SELEJDAK, J., BORKOWSKI, S. (2012). Diagnosis and damage of bearings. In: Manufacturing Technology, Volume 12, Issue 13, UJEP, pp. 140-144.

[10] STASIAK-BETLEJEWSKA, R. (2012). Value engineering as the way of quality problems solving in the steel construction management. In: Manufacturing Technology, Volume 12, Issue 13, UJEP, pp. 242-247.

[11] HRUBEC, J., ŽABÁR, P., PRÍSTAVKA, M., ŠKŮRKOVÁ, K. (2008). Statistics pursing of capability process of sharped matter on roller, Quality of materials and products. pp. 33-38. Publishing and Press Association of Universities Russia, Saint - Petersburg.

[12] BORKOWSKI, S., ULEWICZ, R., SELEJDAK, J., KONSTANCIAK, M., KLIMECKA-TATAR, D. (2012). The use of $3 \times 3$ matrix to evaluation of ribbed wire manufacturing technology, In: $21^{\text {st }}$ International conference on metallurgy and materials (Metal 2012), TANGER Ltd. pp. 1722-1728, Ostrawa.

[13] TIllová, E., CHAluPOVÁ, M., HURTAlOVÁ, L., ĎURINÍKOVÁ, E. (2011). Quality control of microstructure in recycled Al-Si cast alloys, In: Manufacturing Technology, Volume 11, Issue 11, UJEP, pp. 7076. 